\title{
Música e identidades juvenis na cena cultural contemporânea
}

\author{
Elisabete Maria Garbin \\ Doutora em Educação (Universidade Federal do Rio Grande do Sul) \\ Professora na Universidade Federal do Rio Grande do Sul \\ Porto Alegre, Rio Grande do Sul, Brasil \\ emgarbin@terra.com.br \\ Angélica Silvana Pereira \\ Doutora em Educação (Universidade Federal do Rio Grande do Sul) \\ Professora na Universidade Federal de Santa Catarina \\ Florianópolis, Santa Catarina, Brasil \\ angelica.ufsc@gmail.com
}

\begin{abstract}
Resumo Neste artigo pretende-se traçar interlocuções entre duas pesquisas sobre práticas juvenis atreladas à música em diferentes tempos e espaços urbanos. Privilegiam-se recortes que dão ênfase às práticas culturais de jovens que integram diferentes grupos e que têm a música como pano de fundo. Nesta direção, compreende-se a música como uma via pela qual os jovens se apropriam de imagens sociais diversas (etnia, gênero, classe) e de estilos (linguagens, vestimentas, marcas corporais). Tais expressões, entre tantas outras, são práticas culturais cotidianas que adquirem significados em contextos específicos, partilhadas (ou não) com seus pares. Conclui-se que, apesar das diferenças entre os vários estilos de música consumidos pelos jovens, de um modo ou de outro, todos contribuem para a formação e o fortalecimento de suas identidades.
\end{abstract}

Palavras-chave: identidades juvenis, música, práticas culturais.

\section{Introdução}

A música tem sido um dos artefatos culturais mais consumi-

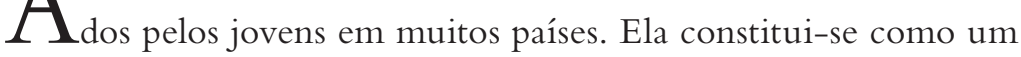
agente de socialização juvenil, "à medida que produz e veicula molduras de representação da realidade, de arquétipos culturais, de modelos de interação" (Dayrell, 2005, p. 35). Além disso, a música acompanha os jovens em muitas situações do seu cotidiano, servindo como trilha sonora para emoções, aventuras, amores, festas, encontros, momentos de introspecção, lazer, euforia e tantos outros.

Neste artigo apresentamos interlocuções entre duas pesquisas sobre práticas juvenis urbanas que têm a música como uma importante via de sociabilidade. A primeira diz respeito a uma investigação que analisou práticas relacionadas à música de jovens estudantes do ensino médio de duas escolas públicas estaduais localizadas na zona central de Porto Alegre. A segunda refere-se a uma pesquisa de doutorado que problematizou práticas juvenis no Parque da Redenção, onde centenas de jovens se reúnem aos domingos à tarde, compondo uma instigante cena urbana. Entre tais práticas, pode-se dizer que as mais acionadas estão relacionadas aos consumos musicais. Com esses dois recortes procuraremos mostrar os arranjos identitários desenhados pelos jovens que participaram dos estudos. 
As pesquisas estão situadas na área da Educação e buscam interlocuções com os Estudos Culturais e os estudos sobre juventudes. A etnografia é a principal referência para a produção de materiais analíticos, a partir dos registros em diários de campo, fotografias, transcrições de conversas e entrevistas.

Nosso objetivo é analisar como a música, na qualidade de artefato cultural, contribui para o processo de construção das culturas e identidades juvenis, mediante implicações entre a produção de estilos e performances, e as relações de amizade, de pertencimento e dos jovens consigo mesmos. A intenção é somarmo-nos às discussões que tematizam as práticas juvenis diversas, especialmente aquelas relacionadas à música. No caso de nossas pesquisas, focalizamos as bandas, os cantores e os diferentes usos e (re)interpretações das músicas por parte dos jovens que integraram o corpo das pesquisas, produzindo múltiplas identidades, sentimentos de pertença e aprendizagens.

Para tal, apoiamo-nos na compreensão de juventudes [no plural] como uma construção que se torna possível a partir de determinadas contingências históricas, econômicas, sociais e culturais. Isso se acentua principalmente a partir das intensas mudanças ocorridas após a Segunda Guerra Mundial, que permitiu múltiplos arranjos culturais, fazendo com que as juventudes estejam se desenhando como uma categoria múltipla e cada vez mais complexa.

Assim como a noção de juventude, as agregações juvenis e as suas relações com a música, bem como os consumos a ela relacionados, não são naturais. São construções históricas e culturais que começaram a ter maior visibilidade na Europa dos anos 1950, com grupos juvenis tidos como marginais, produtores e consumidores de jazz - os beats -, que definiam espaços para os seus encontros, geralmente em bares localizados nos porões de prédios das cidades. Em seguida, com o surgimento do rock'n'roll, a relação entre os jovens e a indústria cultural ficou mais clara. Depois do pós-guerra, setores produtores e difundidores da cultura de massas passaram a investir na criação de um mercado juvenil específico, estimulando um estilo de vestimenta e de outros produtos, como chicletes, refrigerantes, meios de locomoção, como a motocicleta, por exemplo.

Desse modo, foi 'inventada' uma estética juvenil veiculada pelo cinema, pela televisão, pelo rádio, pela mídia em geral, a qual tinha o rock'n'roll como um modo de expressão desse novo 'padrão' de comportamento e de valores, centrados na liberdade, na autonomia e no prazer. Segundo a literatura, na década de 1970 surgiram as maiores diversificações das expressões juvenis, articulando o rock, o visual, as atitudes e diferentes linguagens. Desde então, a partir do rock tornou-se possível uma série de outros desdobramentos de estilos musicais e de vida, tais como o punk rock, o hardcore, o heavy metal, o emocore etc. A música - no caso, o rock - e as relações sociais que se estabeleciam em seus entornos, de algum modo respondiam aos anseios juvenis de encontrar sentidos para a vida, preenchendo espaços vazios (Dayrell, 2005).

Hoje, deparamo-nos com inúmeras possibilidades de apreciação, gostos e consumos musicais juvenis, os quais nos parecem estar sempre atrelados a determinados conceitos, estéticas e valores que atuam nos processos de identificação e de pertencimento dos jovens, sobre os quais trataremos no decorrer deste artigo.

\section{Eu sou um pouco de cada coisa...}

Num canto da sala, uma jovem 'devora' páginas de um livro de poesias, bestseller do momento. Junto à parede, uma jovem digita um torpedo em seu celular; já outra tenta esconder, junto aos cadernos, a última edição de uma revista juvenil, que traz na capa o galã da novela do horário nobre. Um jovem, num outro canto da sala, aguarda a professora passar por entre as carteiras e mochilas 'da hora' espalhadas pela sala, para mostrar aos colegas uma tatuagem no ombro direito; e eis que adentra na sala, esbaforida, uma garota, desfilando um cabelo multicolorido, sussurrando aos colegas: pintei com papel crepom! (...) Toca um celular! E a professora [alheia a isso tudo?] segue explicando a matéria... (Garbin, Diário de campo, 2005)

A cena descrita no excerto acima poderia ser de uma sala de aula qualquer, em qualquer lugar. São expressões que trazem o gosto musical diferenciado dos jovens, sua literatura preferida, a escolha de suas vestimentas, suas linguagens, que falam de seus territórios, suas marcas corporais, que colaboram com a afirmação da sua existência aos olhos dos outros. Expressões essas, entre tantas outras, que nada mais são do que diferentes práticas culturais do cotidiano desses jovens e que adquirem significados em contextos específicos, partilhadas [ou não] com seus pares, e que às vezes, diante das tensões identitárias de toda ordem, levam a condutas compulsivas.

Apesar das diferenças entre os vários estilos de música veiculados pela mídia, todos contribuem para a formação e o fortalecimento de identidades. A música passa a ser uma espécie de fio, de eixo, que vai de casa para a escola e para onde quer que os jovens forem. E à medida que os aparatos tecnológicos se ampliam e se tornam acessíveis, artefatos como música e vídeos podem estar facilmente presentes em espaços e tempos como a escola, as salas de aula, os meios de transporte públicos e outros. Assim, fones de ouvido, telefones celulares e MP3/MP4 têm sido praticamente uma extensão do corpo. 
Além disso, outros investimentos corporais são comuns entre os jovens, a partir das músicas e bandas que apreciam. Com a expansão da indústria do design na contemporaneidade e, entre elas, a indústria do design corporal, tornou-se condição sinequa non, principalmente entre jovens, a busca de uma sobrevalorização do corpo e seus assessórios para marcar sua presença no mundo. É uma espécie de "corrida sem fim para aderir a si, a uma identidade efêmera, mas essencial para si e para um momento do ambiente social", ou seja, "para se tornar notado, multiplicam-se os sinais da sua existência de maneira visível no corpo" (Le Breton, 2004, p. 19).

Os processos cotidianos de fragmentação, somados ao poder da cultura da massa, inscrita em códigos e estilos, gestos e performances, têm nas cenas juvenis um terreno próprio para a formação de identidades. Para Frith (2003), nós absorvemos a música em nossa vida, em nosso ritmo, em nossos corpos e essa é uma experiência de identidade - não algo que se adquira de forma acabada e pontual, e sim um processo gradual, como ilustram os excertos de entrevistas realizadas com os jovens:

Um dia, eu vi um grupo de roqueiros assim, e fui lá conversar com eles e aí começou. Daí, eu comecei a andar que nem eles assim, com as roupas rasgadas, do jeito que eu gostava... (Cássia, 16 anos)

Ultimamente estou me vestindo 'normal'. [...] mas já fui roqueira, já me vesti de preto, de rock androll até a cabeça, mas cansei, cansei, porque é um estilo sem futuro!? (Lana, 17 anos)

Ah, eu sou bem pagodeiro, calça de brim, camisetinha social e é bem a moda, né? (Kaio, 18 anos)

Ewen (1991) argumenta que vivemos na contemporaneidade sob a égide de uma política do estilo, ou seja, que a partir do "estilo" construímos marcas de distinção, de identidade e um lugar no mundo. Já para Carmo (2001, p. 203), "o grupo e o indivíduo passam a ser reconhecidos pelos adereços e vestimentas que usam, e o estilo torna-se importante expressão da identidade do grupo e dos ideais por ele adotado".

Esses estilos podem ser híbridos, apresentando muitas vezes tênues fronteiras e contradições, como se pode observar nos excertos a seguir:

Eu sou um pouco de cada coisa, eu não acho que eu sou punk, que eu sou roqueira, somente. Eu gosto mais de metal, mas eu não sou... Eu sou um pouquinho de cada coisa! (Cássia, 16 anos)

Eu sou um jovem bem pagodeiro! (Júlio, 17 anos)
Logo que eu comecei a escutar rock androll [...] eu mudei totalmente. Agora eu vou andar de preto, eu vou pôr um piercing, vou fazer isso, vou fazer aquilo, vou pintar meu cabelo de vermelho, vou fazer 'não sei o quê' no meu cabelo, vou fazer 'espeto', [...] influencia muito, sim. (Lana, 17 anos)

Os discursos dos jovens, conforme visto nesses depoimentos, demonstram o hibridismo, o "tingimento" identitário que os interpela. É uma espécie de declaração: "Eu sou [eu estou] o que eu ouço, neste momento, neste lugar, neste contexto". Valdívia (1999) afirma que "a música ocupa tanto um lugar de destaque quanto de disputa, uma vez que todos nós somos levados a definir e afirmar nossas identidades, em parte através das nossas atividades e escolhas musicais" (p. 64).

Woodward (2000), ao referir-se aos investimentos de identidade, sugere que os termos identidade e subjetividade se cruzam de alguma maneira. Para a autora, "subjetividade sugere a compreensão que temos sobre o nosso eu [...], envolve os pensamentos e as emoções conscientes e inconscientes que constituem nossas concepções sobre 'quem somos nós' [...], nossos sentimentos e pensamentos mais pessoais" ( $\mathrm{p}$. 55). Assinala ainda que vivemos nossa subjetividade em um contexto social no qual a linguagem e a cultura dão significado à experiência que temos de nós mesmos e no qual nós adotamos uma identidade. Isto sugere pensar que, em parte, as pessoas são sujeitadas ao discurso e devem, elas próprias, assumi-los como indivíduos que, dessa forma, se posicionam a si próprios. Assim, as posições que assumimos e com as quais nos identificamos são constitutivas de nossas identidades.

Nesse sentido, Woodward (2000) observa que fatores sociais podem explicar a construção particular de uma identidade e seus atributos num momento específico da história, da sociedade e da cultura, mas nem sempre explicam que investimentos os indivíduos fazem nas posições específicas que ocupam e as relações que estabelecem com e a partir de tais posições.

Como explicar, por exemplo, as perguntas feitas por mães às professoras de música de escolas, do tipo: "Por que, dos dois filhos que eu tenho, cada qual prefere e consome estilos de música completamente diferentes um do outro, mesmo tendo sido expostos aos mesmos gêneros musicais de nossa preferência [referindo-se às preferências dos pais] e tendo o mesmo acesso a audiências musicais"?

Não temos respostas para tais perguntas, mas algumas suposições. Uma delas ancora-se na ideia de que os jovens podem não ser consumidores passivos, totalmente manipuláveis pela indústria fonográfica ou mesmo pelos gostos musicais de seus pais. Acreditamos que eles vão construindo suas referências identitárias, bem como suas próprias identidades. 
Nesse caso, tanto as referências quanto as identidades podem ser híbridas, num misto entre as músicas em ampla circulação midiática, as músicas ouvidas e apreciadas por seus pares e também pelos grupos que funcionam como um sinal distintivo e de recusa.

Pudemos verificar- em entrevista por telefone com diretores de departamento de televisão de grandes gravadoras, tais como a Emi e a Warner,e que são aqueles que determinam os estilos dos videoclipes que irão veicular a música de uma banda, de um cantor ou de uma cantora que deverá "emplacar" [a chamada "música de trabalho"] - que há, sim, um direcionamento destas ao consumo de mercado, principalmente no lançamento de CDs e "jabás" pagos às rádios oficiais.

Por outro lado, pudemos também constatar que a maioria dos jovens entrevistados conhece os diferentes gêneros musicais que consome e é capaz de escutar, localizar histórias de seus ídolos, influências e fontes musicais. Muitos deles estudam música, tocam um tipo de instrumento, entretanto, em sua maioria, buscam aproximar-se do repertório de sua preferência musical, como que para dizer a si mesmo e aos outros: "Eu já toco duas músicas deles”!Esses jovens não hesitam em emitir seus juízos de valor sobre a música que consomem e sobre as que gostam ou não. Seus padrões de consumo são também complexos e não sinalizam um simples assujeitamento à indústria fonográfica e seus tentáculos.

Outro aspecto que chamou-nos a atenção na pesquisa diz respeito aos investimentos corporais capazes de inscrever nos corpos dos jovens sinais de identidade atrelados à música e que não são facilmente apagados ou trocados, tais como piercings e tatuagens.

Eu tenho um piercing no queixo... Tenho uma tatuagem no pulso 'Amor e Loucura', outra nas costas 'Vida Louca' e uma estrelinha na barriga. [...] 'Vida Louca' é título de uma música do Cazuza, porque a minha vida é muito louca, assim... (Angel, 18 anos)

Ah, eu faria símbolos do Guns, sabe? Bandas de rock androll. (Diogo, 21 anos)

Eu não tenho tatuagem, eu não tenho piercing, mas eu queria ter. Meu pai não deixa. [...] eu faria um desenho do Canibal C dum C que tem, ou faria o pentagrama do Crisan. (Cássia, 16 anos)

Em suas narrativas, os jovens parecem utilizar seus corpos como um texto comunicativo gerador, armazenador e transmissor de informações culturais, no caso, a música (Le Breton, 2004).

Eu fiz ela [referindo-se à tatuagem] em homenagem a uma música do Children of Botton, que é uma música que eu acho bem legal, curto pra caramba, aquela música, é a melhor música que eu acho deles. O nome da música significa estripador [...]. É morte. Muitas pessoas ficam falando 'Ah, tu vai morrer porque tu botaste a tatuagem', não, nada a ver. Se tu vai acreditar no que os outros falam, é muito difícil... (Jo, 18 anos)

Seus discursos indicam que as marcas servem, sobretudo, às intenções do estilo, "ao conservar o estatuto de acessórios para adornar o corpo e compor um visual, construído no sentido de se demarcar socialmente ao marcar um estilo próprio, singular e autêntico" (Ferreira, 2004, p. 96). Sob o reinado do olhar, a superfície torna-se o lugar da profundidade. Para se destacar do fundo de indiferenças, convém, pois, tornar-se visível se se quiser escapar do anonimato.

A originalidade do vestuário, do penteado, da atitude etc., ou, bem entendido, a tatuagem, o piercing, as escarificações, o branding etc. são meios de sobrevalorizar o corpo e afirmar a sua presença para si e para os outros. São sinais para não se passar despercebido e, logo, para existir aos olhos dos outros, ou pelo menos ter-se disso o sentimento (Le Breton, 2004, p. 19).

Segundo Woodward (2000, p. 15), “o corpo é um dos locais envolvidos no estabelecimento de fronteiras que definem quem nós somos, servindo de fundamento para a identidade". Para Sant'Anna (2001), tatuagens desenhadas pelo corpo "vestem e despem ao mesmo tempo as subjetividades de cada um". Ela pode ser concebida como "uma forma de comunicação corporal, na qual cada tatuado se dispõe às incisões da história, há muito responsável por marcar os corpos para melhor socializa-los". A autora segue argumentando que "a riqueza cultural que representa a tatuagem como vestimenta encarnada e, igualmente, como uma metamorfose que vai muito além da própria pele [...]. A tatuagem demarca e circunscreve" (Ramos, 2001, p. 13), demarca grupos, "alimenta códigos de sociabilidade, fomenta saberes especializados e constitui um mundo de imagens" (p. 14).

\section{Eu só sou um cara que gosta de música}

Como parte da metrópole, a partir do meio das tardes de domingo o Parque da Redenção é 'habitado' temporariamente por centenas de jovens 'estranhos', que parecem poluir a busca da ordem normalizadora da cidade. Por causa do grande afluxo de pessoas, o Parque torna-se um lócus propício para as performatividades desses jovens, compondo uma instigante e inquietante cena urbana.

A grande maioria dos jovens porta em seus corpos símbolos que identificam seus gostos musicais, tais como camisetas com bandas e/ou com letras de músicas, e acessórios característicos dos estilos musi- 
cais que apreciam. Na praça, cantam músicas de artistas e de bandas prediletas, além de conversar sobre o assunto, como se pode constatar no excerto de fala a seguir:

As pessoas passam e não gostam de ver a gente aqui [referindo-se à Redenção]. Mas eu, por exemplo, eu só sou um cara que gosta de música... Aqui, todo mundo discute sobre música como se estivesse discutindo futebol, entendeu? Então, é aquela coisa assim... além de discutir tu consegues fazer amizades, aqui tu bebes, tu te divertes... (Beto Ramone)

Há certa relação entre o consumo de drogas lícitas e ilícitas com alguns eventos de música, por exemplo, shows de rock e suas variações, reggae etc. Serrano (1998) argumenta que muitas vezes os territórios de expressões juvenis são espaços de distanciamento dos jovens com o mundo adulto, ou, pelo menos, dos adultos que representam certo controle em suas vidas, como pais, familiares, professores e autoridades, favorecendo determinadas práticas.

O que ocorre na Redenção aos domingos não é um "evento" de música, mas adquire um sentido parecido para alguns jovens, por ser um espaço de compartilhamento de gostos e estilos musicais,e ao mesmo tempo de marcação das diferenças, e no qual a presença de adultos que possam regular suas condutas é praticamente inexistente.

Durante essa pesquisa, foram muitos os depoimentos que apresentaram a música como um modo de vida, e não como algo de fora ou exterior às suas experiências.

A música é muito mais pra mim... É uma filosofia de vida, é um jeito de pensar, de se expressar e de se relacionar com as pessoas. (Toad Ramirez)

Talvez esse seja um ponto forte que nos permite entender as relações dos sujeitos - principalmente dos jovens - com a música. Pode-se inferir, então, que esta parece operar significativamente na construção das subjetividades dos jovens. Segundo Frith (2003), a música é uma prática estética que articula uma compreensão tanto das relações grupais quanto da individualidade. Assim, ela não é apenas uma forma de expressar ideias, mas também de vivê-las.

Para Dayrell (2005), a música coloca à disposição dos jovens a possibilidade de entrelaçar as tramas de um caminho de busca existencial com os signos de uma presença coletiva. Desse modo, a música parece operar como um elemento-chave para as construções identitárias dos jovens, na medida em que ela oferece a possibilidade de uma apresentação de si e dos outros, do subjetivo e do coletivo (Frith, 2003). Como afirma Dayrell (2005), por meio da música, as necessidades dos jovens de uma ancoragem e a agregação coletiva são articuladas com trajetos que se configuram em experimentações de si mesmos.

O que podemos constatar no parque é que o rock e suas derivações é o estilo musical preponderante entre os jovens. "Nós curtimos rock'n'roll, mas cada um curte um estilo de rock. Tem divisões", comentou uma jovem em uma de nossas conversas. Um amigo completou: "Porque o rock é um estilo dividido em várias espécies. Então aqui, cada um tem a sua espécie do rock". Muitos se dizem roqueiros; outros, metaleiros, góticos, punks, emos.

O estudo de Garbin (2001) enfatiza que muitos jovens buscam outros com quem possam compartilhar os mesmos gostos musicais, as mesmas bandas, enfim, de traços de identificação que têm a música como pano de fundo, visando a inclusão, o pertencimento e o reconhecimento. Assim, mediante as preferências musicais, é possível sentir-se pertencendo a um grupo, a uma tribo e também estabelecer algumas fronteiras que marcam diferenças entre esses grupos, como se pode observar no seguinte excerto de fala de uma jovem:

Aqui, no parque, o chafariz é o limite. Do chafariz pra lá, são os normais que ficam, tipo, os vestidos normalzinho, os heteros... Do chafariz pra cá são os roqueiros, os emos, os metaleiros, os bissexuais. No Arco, são os emos que ficam mais. Aqui, ficam os roqueiros. De vez em quando a gente caminha no meio deles, e eles, no meio de nós, mas a gente sabe quem curte o quê. (Bru)

Essas fronteiras estabelecidas entre os jovens frequentadores do parque mostram que aquele espaço-tempo pode ser vivido de diferentes maneiras, mediante distintas dinâmicas de amizade, visibilidade, expressividade, diversão. Nesse sentido, ressurge na fala da jovem Bru a figura do "normal", daquele sujeito que aparentemente demonstra cumprir o conjunto de normas sociais inventadas e estabelecidas, tais como vestir-se "adequadamente" e demonstrar comportamentos esperados para aquele lugar. Já no espaço dos "anormais", uma série de práticas estaria "permitida", como forma possível de contestação às normas, ao código moral da sociedade.

Entretanto, entre esses jovens "anormais" também parece existir formas de classificação e de marcação da diferença, mediante a apropriação e a significação de pontos do parque. Assim, dois pontos de grande visibilidade são ocupados pelos jovens. Um deles é o Arco - modo como o Monumento de Expedicionário é chamado entre os jovens, por causa de seu formato em arcos -, que atualmente é mais demarcado por jovens emos. O outro é uma espécie de corredor formado por bancos no caminho de acesso a um dos banheiros públicos do parque, formando uma espécie de "passarela do rock", por onde transitam os 
jovens exibindo seus estilos que, em sua maioria, são estilos musicais. Lá ficam muitos jovens que se dizem roqueiros, metaleiros, punks e que abominam o estilo musical emocore.

$\mathrm{Na}$ "passarela do rock" é possível deslocar-se com grande visibilidade. Muitos jovens passam a maior parte do tempo no trânsito entre o Arco e a "passarela do rock" e outros recantos do parque. Segundo Almeida e Tracy (2003), esses nomadismos traduzem-se em um "conjunto de práticas espaciais que transformam os lugares em uma experiência transespacial, na qual o circuito é constituído por trajetórias simultâneas" (p. 41). Nesses circuitos, os jovens mostram-se fortemente performáticos, o que, segundo Pais (2006), pode estar relacionado com a falta de uma identificação deles com as culturas prescritivas que a sociedade lhes impõe, desencadeando, assim, essas expressividades performáticas

Nessa direção, Giberti (1998) aponta que o rock dispõe de seus discursos próprios, conforme a época em que se desenvolve e as ideologias de cada banda. Esse estilo musical também conta com os discursos e outras produções do seu público, por exemplo, as roupas, que adquirem uma importância particular, o corte ou o penteado do cabelo, os acessórios e outros aspectos capazes de compor, ao mesmo tempo, imagens de um estilo e imagens de si. Garbin (2001) destaca que o look, a fachada, a roupa e outros objetos usados pelos jovens funcionam como sinais, como emblemas que lhes permitem ascender ou não à sua tribo, ao seu grupo.

Dayrell (2005) chama a atenção para a importância da relação cada vez mais estreita entre música-visual-vida, que vem se configurando naquilo que Featherstone (1995) denomina "estetização da vida cotidiana" (p. 100), que pode ser exibida, mostrada. Pode-se inferir que os jovens deste estudo inventam suas estéticas cotidianas mediante a incorporação de determinados estilos de vida, que são exibidos em distintos espaços e de diferentes maneiras, como se observa no excerto de fala que segue:

A gente quer mostrar para os outros que a gente não é do estilo deles. Tipo, tem os playboyzinhos, têm os manos do rock, né? Nada contra eles, mas a gente quer mostrar que a gente não curte aquilo que eles curtem, que eles têm um estilo diferente. (Jovem não identificado)

Já no próximo excerto de fala, o jovem evidencia outra estratégia de criação estética, por meio da composição de uma banda de punk rock com o nome de Katarro. Ao ser perguntado sobre o porquê de tal nome, respondeu:

Ninguém gosta de ver um catarro! É uma coisa que causa asco, mesmo, ninguém gosta de ver. Por mais que todo mun- do largue seus catarros nem que seja no chuveiro quando tá gripado, é uma coisa que ninguém gosta de ver o do outro. Então eu acho que é mais uma forma de chocar. E uma coisa que choca, incomoda... O nosso som também incomoda porque é ruim pra caralho! [risos] É mais outra forma de quebrar padrões. Ao invés de Capital Inicial ou Calypso, é Katarro! (Rafael)

Para Featherstone (1995), a estetização da vida cotidiana são fluxos velozes de signos e imagens que saturam e tramam a contemporaneidade. Isto significa dizer que a espetacularização tem como principais mediadores o olhar e o visual (Dayrell, 2005), apontando assim para o que Debord (1997) designou de sociedade do espetáculo.

Essa estetização da vida cotidiana, segundo Featherstone (1995), diz respeito a estratégias de apagamento de fronteiras entre ela e a arte, transformando a própria vida numa obra de arte. Nesta perspectiva, a noção de estética distancia-se dos padrões de beleza hedonista, mas está imbricada com o exercício de deixar-se afetar pelo mundo e pelo outro. Portanto, ao olharmos para as práticas culturais desses jovens, poderemos enxergar como determinadas verdades estão associadas a um cardápio de regras morais, consideradas válidas e legítimas socialmente, e como tais jovens tentam lidar com elas. Para refletir sobre tais assertivas, trazemos a seguir o excerto de fala de um jovem punk sobre a importância da música na sua vida:

A música é uma forma de expressão, muitas vezes do meu ódio. Geralmente quando eu escrevo alguma letra, eu tô com raiva de alguma coisa que eu vi na televisão, eu tô com raiva de alguma coisa que me acontecen na rua, de alguma coisa que eu pensei que me fez lembrar de alguma coisa que me causa raiva. Isso é música pra mim. A música, pra mim, tem de ser feita com um certo ódio. (Rafael)

O mesmo pode-se constatar no excerto de fala da jovem Roxinha, conforme a seguir.

Uns dois anos atrás, por aí, eu não era roqueira. Mas daí eu vi que comecei a curtir rock e comecei a ter um jeito diferente de pensar. É que as pessoas [do rock] não tinham muito preconceito, independente de quem tu fosses, entendeu?! Daí eu comecei a... bah!, a curtir rock com uma amiga e comecei a ver o outro lado, porque eu pensava que ser roqueiro era só fumar maconha e esses troços. Mas, de repente, no começo do ano passado eu conheci pessoas que eu vi que eu podia contar com elas, que estariam do meu lado. Pessoas que têm uns pensamentos bem legais. Eram contrao capitalismo, contra o nazismo, contra o racismo e eu achei muito legal isso. Acho que, bah!, isso é muito importante. Elas gostavam de músicas que falavam dessas coisas e outras músicas falam só de amor e essas coisas assim. Eles escrevem músicas e não ficam 
fantasiando o mundo. Nesse sentido a música é muito importante, a música se destaca, a música é tudo. (Roxinha)

A música, uma fonte de inspiração entre os jovens, principalmente no que diz respeito à sua vida cotidiana, é uma das principais formas pela qual eles se apropriam das imagens sociais, sejam elas de etnia, gênero e classes sociais, sejam de estilos, ainda que pouco falem sobre essas diferenças. As músicas que eles consomem é que falam sobre tais diferenças e às vezes falam por eles.

Gil (2003), em sua pesquisa sobre práticas educativas em grupos juvenis de música e religião de Santo Antônio da Patrulha, expõe que os jovens criam sentidos para as suas experiências e se constituem como sujeitos a partir dos processos de socialização compostos por múltiplas interações, tecendo uma trama que se abre para inúmeras opções e também por muitas limitações. "Impossível, portanto, pensar isto numa lógica determinista, com a socialização reduzida a um treino que propicia a [simples] interiorização de regras e valores" (Gil, 2003, p.62). É neste sentido que a invenção de uma outra 'estética de si' se desenha. Jovens pensam em estratégias ou em ações nas quais a novidade pode ser criada, contrapondo-se a lógicas deterministas que pretendem lhes inculcar valores $\mathrm{e}$ normas (Pereira, 2011). Isso requer um incessante trabalho sobre si, a partir de infinitas experimentações, as quais parecem se tornar possíveis no interior das redes de relações que são construídas em espaço-tempos mais ou menos institucionais, por exemplo, o Parque da Redenção aos domingos.

Esses consumos musicais fortemente implicados em processos de identificação juvenis são causadores de repulsas e aproximações. Em relação às aproximações, constatou-se que a amizade e/ou o sentimento de pertença a um grupo foi o argumento bastante referido pelos jovens para justificar a importância de frequentar o parque aos domingos. Essas amizades são totalmente implicadas com os gostos e consumos musicais, como se pode observar no excerto a seguir.

Deixa eu gravar uma coisa aí... Eu venho aqui pro Arco [referindo-se ao Monumento do Expedicionário] todo domingo faz mais de quatro anos. Venho para curtir com a galera, para curtir com os amigos. Beber uma bira, conhecer gente nova, conhecer novas bandas de rock androll. O lugar onde eu tenho mais amigos é aqui no Arco. Eu chego no Arco já com a mão levantada para cumprimentar todo mundo. Não posso botar a mão no meu bolso porque sempre tem um amigo meu que vai vir me cumprimentar. Eu conheço muita gente. Tudo por causa do Arco! (Jovem não identificado)

A gente vem aqui aos domingos, não todos, quando a gente tem grana [...]. Aqui é um lugar que todo mundo se respeita, é um lugar que tem muita gente do nosso estilo aqui. Gente que curte as mesmas bandas que a gente, que se veste como a gente... É por isso que a gente gosta da Redenção. (Toad Ramirez)

Pode-se inferir, a partir de tais excertos, que os modos como os múltiplos recantos do parque são reinventados, vividos e praticados pelos jovens que montam o espetáculo ou que portam o espetáculo em seus corpos aos domingos assumem uma dimensão afetiva mesclada com a busca de prazer e de diversão, nos quais a música assume grande importância.

No espaço compartilhado e visibilizado, os jovens experimentam o caráter público da amizade e vivem formas diversas de sociabilidades, criando vínculos que parecem ter, naquele momento, a mesma ou a maior importância do que os vínculos orgânicos (Ortega, 2002). Assim torna-se possível inventar modos de estar juntos que saem, em parte, do domínio ou do controle dos adultos, favorecendo um caráter transgressor e ao mesmo tempo criativo dessas relações de amizade que muitas vezes têm a música como elemento atrator e agregador (Pereira, 2011).

\section{Enfim...}

Cercados por todos os lados pela ideia de consumo, há de se destacar que os jovens, especialmente os adeptos das culturas juvenis espetaculares (Feixa, 1999), parecem aderir aos códigos de consumo que estão na moda e, a partir deles, inventam estéticas e comportamentos, aproximando-se de uma espécie de tendência inovadora (Feixa, 1999), as quais passam a circular nos seus espaços de encontro. Isso se tornou visível nos arranjos estéticos exibidos nos corpos dos jovens, mediante combinações que buscaram privilegiar o toque de singularização. Nessa perspectiva, as práticas de consumo necessitam ser pensadas na sua complexidade, para além de uma visão utilitarista, já que elas passam a ser uma via pela qual se pode perseguir e construir a diferenciação perante os demais.

As análises mostraram também que muitos jovens, além de usarem as vestimentas para comunicar sua maneira de ser e seus gostos musicais, passaram a portar símbolos e mensagens expressos no corpo, nos adereços na forma de tatuagens, piercings. Vemos, assim, que a música e os investimentos em diferentes gostos musicais em muitos momentos estão atrelados a diferentes usos e reinterpretações de estilos e que os jovens podem ressignificá-los de diversas formas, valorizando alguns como suporte de comunicação com seus pares e recusando outros.

A aproximação de jovens com gostos parecidos e atitudes comuns num cenário de diversão, como é o caso do parque ou da escola, faz parte de um 
processo de identificação que depende também dos códigos e símbolos culturais com os quais eles não se afinam e até mesmo repulsam. O fato é que esses códigos e símbolos são extremamente diversificados, e mesmo que suas adesões a eles nos permitam nomeá-los como metaleiros, roqueiros, pagodeiros, rappers, punks, regueiros, grunges, nerds, boyzinhos, luluzinhas, burguesinhos, manos, skinheads, patricinhas, mauricinhos, funkeiros, skatistas e outros, ainda assim parece-nos impossível pensá-los a partir de definições estáveis e seguras. Seus gostos, seus pertencimentos e suas identidades são móveis, cambiantes e provisórios.

Das revoluções culturais dos nossos tempos, a chamada "cultura da mídia" - em sua dimensão global, incluindo-se nela as tecnologias virtuais - resulta numa espécie de mix cultural sustentado pelas diferenças das condutas de jovens em suas práticas culturais e que podem ser constatadas em grupos diversificados em uma mesma sala de aula. Somos interpelados incessantemente por símbolos do consumo que, ao mesmo tempo em que nos constituem dessa ou daquela maneira, acabam sendo ressignificados a todo o momento.

\section{Referências}

ALMEIDA, Maria Isabel M.; TRACY, Kátia M. de A. Noites nômades: espaço e subjetividade nas culturas jovens contemporâneas. Rio de Janeiro: Rocco, 2003.

CARMO, Paulo S. do. Culturas da rebeldia: a juventude em questão. São Paulo: Ed. Senac, 2001.

DAYRELL, Juarez. A música entra em cena: o rap e o funk na socialização da juventude. Belo Horizonte: Ed. UFMG, 2005.

DEBORD, Guy. A sociedade do espetáculo. Rio de Janeiro: Contraponto, 1997.

EWEN, Stuart. Todas las imágenes del consumismo: la política del estilo em la cultura contemporánea. México, DF: Editorial Grijalbo, 1991.

FEATHERSTONE, Mike. Cultura de consumo e pósmodernismo. São Paulo: Studio Nobel, 1995.

FEIXA C. De culturas, subculturas y estilos. In:

De jóvenes, bandas y tribus. Barcelona: Ariel, 1999. p. 84-105.

FERREIRA, Vítor S. Do renascimento das marcas corporais em contextos de neotribalismo juvenil. In: PAIS, José M.; BLASS, Leila M. da S. Tribos urbanas: produção artística e identidades. Pinheiros, SP: Annablume, 2004. p. 71-102.

FRITH, Simon. Música e identidad. In: HALL, Stuart; DU GAY, Paul (Comps.). Cuestiones de identidad cultural. Buenos Aires: Amorrotu, 2003. p. 181-213.

GARBIN, Elisabete Maria. www.identidadesmusicaisjuvenis. com.br: um estudo de chats sobre música da Internet.
Logo, se problematizarmos juventude(s) com as lentes da cultura, podemos vê-la(s) como, no mínimo, comunidade(s) de estilo(s), atravessada(s) por identidades de pertencimento, como o look de suas vestimentas e adereços, incluindo aqui estilos musicais, comportamentos, gírias, atitudes corporais etc. Pode-se observar que parte significativa dos jovens que participaram das pesquisas usa um tipo de vestimenta e de adereços que corresponde ao estilo musical que vem consumindo, e/ou mostram seus sinais de identidade mediante o uso de piercings, brincos, tatuagens e outros tipos de marcas corporais. Ou seja, os jovens buscam afirmar uma singularidade que pode não indicar uma forma de dissidência ou inconformismo sociais, de "protesto contra o sistema capitalista", ou "protesto contra as regras hipócritas do mundo adulto", e sim uma prática que simplesmente significa "estar na moda", "ser do grupo".

Assim, as possibilidades de outras experimentações, de novos amigos, de novos pertencimentos, de outras relações afetivas, bem como o crescimento assustador das possibilidades de consumo, potencializam reinvenções identitárias infinita e indefinidamente.

Tese (Doutorado em Educação). Faculdade de Educação, Universidade Federal do Rio Grande do Sul. Porto Alegre, 2001.

Se Liga!! Nós estamos na Escola!! Drops sobre culturas juvenis contemporâneas. Jornal NH, Novo Hamburgo, setembro 2005. (Caderno Cultura NH na Escola).

GIBERTI, Eva. Hijos del rock. In: CUBIDES, Humberto J.; TOSCANO, María Cristina L.; VALDERRAMA, Carlos Eduardo H. (Eds.). Viviendo a toda: jóvenes, territorios culturales y nuevas sensibilidades. Fundación Universidad Central. Santafé de Bogotá: Paidós, 1998. p. 173-193.

GIL, Carmem Zeli Vargas. No tecer da vida, a juventude; no tecer da juventude, a vida: práticas educativas de jovens de Santo Antônio da Patrulha, em grupos de música e religião. Porto Alegre: UFRGS, 2003. Dissertação (Mestrado em Educação). Faculdade de Educação, Universidade Federal do Rio Grande do Sul. Porto Alegre, 2003.

LE BRETON, David. Sinais de identidade: tatuagens, piercings e outras marcas corporais. Lisboa: Miosótis, 2004. ORTEGA, Francisco. Genealogias da amizade. São Paulo: Iluminuras, 2002.

PAIS, José Machado. Prefácio. In: ALMEIDA, Maria Isabel de; EUGENIO, Fernanda. Culturas jovens: novos mapas do afeto. Rio de Janeiro: Jorge Zahar Editor, 2006. PEREIRA, Angélica S. Domingo no parque: notas sobre a experiência de ser jovem na contemporaneidade. Tese 
(Doutorado em Educação) - Faculdade de Educação, Universidade Federal do Rio Grande do Sul, Porto Alegre, 2011.

SANT'ANNA, Denise B. de. Apresentação. In: RAMOS, Célia M. A. Teorias da tatuagem: corpo tatuado: uma análise da loja Stoppa Tatoo da Pedra. Florianópolis: UDESC, 2001

SERRANO, José Fernando. "Somos el extremo de las cosas" o pistas para comprender culturas juvenileshoy. In: CUBIDES, Humberto J.; TOSCANO, María Cristina L.; VALDERRAMA, Carlos Eduardo H. (Ed.). Viviendo a toda: jóvenes, territorios culturales y nuevas sensibilidades.
Fundación Universidad Central. Santafé de Bogotá: Paidós, 1998. p. 241-260.

VALDÍVIA, Angharad N. Repensando a pedagogia para o século XXI: garotas adolescentes, cultura popular e a política de identidades juvenis. In: SILVA, Luiz H. da (Org.). Século XXI: qual conhecimento? Qual currículo? Petrópolis, RJ: Vozes, 1999.

WOODWARD, Kathryn. Identidade e diferença: uma introdução teórica e conceitual. In: SILVA, Tomaz T. (Org.). Identidade e diferença: a perspectiva dos estudos culturais. Petrópolis, RJ: Vozes, 2000.

\title{
Music and youth identities in contemporary cultural scene
}

\begin{abstract}
This article intends to establish dialogues between two studies on youth practices linked to music in different times and urban areas. The cultural practices of young people who integrate different groups are emphasized specially to whom music is the major interest. In this way, music is understood as a means by which young people appropriate various social images (as ethnicity, gender, class) and style (as language, dressing, bodily marks). Such expressions, among many others, are daily cultural practices which acquire meanings in specific contexts, shared (or not) with their peers. Despite of the differences between the various musical styles absorbed by young people, in one way or another, everybody contributes to the formation and strengthening of their identities.
\end{abstract}

Key words: youth identities, music, cultural practices.

\section{Música e identidades juveniles en la escena cultural contemporánea}

\section{Resumen}

En este artículo se pretende trazar el diálogo entre dos estudios sobre las prácticas de los jóvenes vinculados a la música en diferentes momentos y espacios urbanos. Se dio preferencia a recortes que hacen hincapié en las prácticas culturales de los jóvenes que forman parte de diferentes grupos y tienen música de fondo. En este sentido, entendemos la música como un medio para que los jóvenes se apropien de varias imágenes sociales, ya sean de origen étnico, de género, de clase o de estilo como el idioma, la vestimenta, las marcas corporales. Tales expresiones, entre muchas otras, son prácticas culturales cotidianas que adquieren significados en contextos específicos, compartidas [o no] con sus compañeros. Llegamos a la conclusión de que, a pesar de las diferencias entre los distintos estilos de la música consumida por los jóvenes, de una forma u otra, contribuyen a la formación y el fortalecimiento de sus identidades.

Palabras clave: identidades juveniles, música, prácticas culturales. 